Cellular Physiology
and Biochemistry and Biochemistry Published online: March 11, 2016

Accepted: February 15, 2016

This aricle is licensed under the Cre tional License (CC BY-NC-ND) Creative Commons Attribution-NonCommercial-NoDerivatives 4.0 International License (CC BY-NC-ND) (http://www.karger.com/Services/OpenAccessLicense). Usage and distributio for commercial purposes as well as any distribution of modified material requires written permission.

\title{
Stimulating Effect of Elvitegravir on Suicidal Erythrocyte Death
}

\author{
Rosi Bissinger abdulla Al Mamun Bhuyan ${ }^{a, b}$ Elena Signoretto ${ }^{a, b, c} \quad$ Florian Lang Alb $^{a, b}$
}

Departments of a Cardiology \& Vascular Medicine, and 'bPysiology, University of Tübingen, Tuebingen, Germany; 'Department of Pharmacological and Biomolecular Sciences, Università degli Studi di Milano, Milano, Italy

\section{Key Words}

Phosphatidylserine $\cdot$ Cell volume $•$ Eryptosis $・$ SB203580 • zVAD • Calcium

\begin{abstract}
Background/Aims: The antiviral drug Elvitegravir is used for the treatment of Human Immunodeficiency Virus (HIV) infections. The present study explored whether the drug is able to trigger eryptosis, the suicidal death of erythrocytes. Eryptosis is characterized by cell shrinkage and cell membrane scrambling with phosphatidylserine translocation to the erythrocyte surface. Stimulators of eryptosis include increase of cytosolic $\mathrm{Ca}^{2+}$ activity $\left(\left[\mathrm{Ca}^{2+}\right]_{\mathrm{i}}\right)$, oxidative stress, ceramide, activated p38 kinase and activated caspases. The present study explored, whether Elvitegravir induces eryptosis and, if so, to shed light on the mechanisms involved. Methods: Phosphatidylserine abundance at the erythrocyte surface was estimated from annexin-V-binding, cell volume from forward scatter, $\left[\mathrm{Ca}^{2+}\right]_{i}$ from Fluo3-fluorescence, abundance of reactive oxygen species (ROS) from DCFDA dependent fluorescence, and ceramide abundance at the erythrocyte surface utilizing specific antibodies. Results: A 48 hours exposure of human erythrocytes to Elvitegravir $(\geq 1.5 \mu \mathrm{g} / \mathrm{ml})$ significantly increased the percentage of annexin-V-binding cells, and significantly decreased forward scatter. Elvitegravir $(2.5 \mu \mathrm{g} / \mathrm{ml})$ significantly increased Fluo3-fluorescence, but did not significantly modify DCFDA fluorescence or ceramide abundance. The effect of Elvitegravir on annexin$\mathrm{V}$-binding was significantly blunted by removal of extracellular $\mathrm{Ca}^{2+}$, but not in the presence of p38 kinase inhibitor SB203580 $(2 \mu \mathrm{M})$ or in the presence of pancaspase inhibitor ZVAD (10 $\mu \mathrm{M})$. Conclusions: Elvitegravir triggers cell shrinkage and phospholipid scrambling of the erythrocyte cell membrane, an effect in part due to entry of extracellular $\mathrm{Ca}^{2+}$.
\end{abstract}

(C) 2016 The Author(s)

Published by S. Karger AG, Basel

\section{Introduction}

The viral integrase inhibitor [1] Elvitegravir is an antiretroviral drug [1-5] used for the treatment of Human Immunodeficiency Virus (HIV) infections [1, 2, 4-16]. 


\section{Cellular Physiology Cell Physiol Biochem 2016;38:1111-1120 \begin{tabular}{l|l|l|} 
and BOI: 10.1159/000443061 2016 & $\begin{array}{l}\text { C) 2016 The Author(s). Published by S. Karger AG, Basel } \\
\text { www.karger.com/cpb }\end{array}$
\end{tabular} \\ Bissinger et al.: Elvitegravir-Induced Eryptosis}

Several related other antiviral drugs, such as nelfinavir [17], saquinavir [18] and lopinavir [19] have been shown to trigger eryptosis, the suicidal death of erythrocytes characterized by cell shrinkage [20] and cell membrane scrambling with phosphatidylserine translocation to the cell surface [21]. Signaling underlying stimulation of eryptosis include $\mathrm{Ca}^{2+}$ entry with increase of cytosolic $\mathrm{Ca}^{2+}$ activity $\left(\left[\mathrm{Ca}^{2+}\right]_{\mathrm{i}}\right)[21]$, ceramide [22], caspases [21, $23,24]$, as well as several kinases including casein kinase $1 \alpha$, Janus-activated kinase JAK3, protein kinase C, and p38 kinase [21]. Eryptosis is inhibited by AMP activated kinase AMPK, cGMP-dependent protein kinase, PAK2 kinase, mitogen- and stress-activated kinase MSK1/2 and sorafenib/sunitinib sensitive kinases [21,25]. Eryptosis is triggered by oxidative stress [21], energy depletion [21] and a wide variety of xenobiotics [18, 21, 26-55].

The present study explored, whether Elvitegravir stimulates eryptosis. To this end, human erythrocytes drawn from healthy volunteers were treated with Elvitegravir and phosphatidylserine surface abundance, cell volume, $\left[\mathrm{Ca}^{2+}\right]_{i}$, abundance of reactive oxygen species (ROS) and ceramide determined by flow cytometry.

\section{Materials and Methods}

\section{Erythrocytes, solutions and chemicals}

Fresh Li-Heparin-anticoagulated blood samples were kindly provided by the blood bank of the University of Tübingen. The study is approved by the ethics committee of the University of Tübingen (184/2003 V). The blood was centrifuged at $120 \mathrm{xg}$ for $20 \mathrm{~min}$ at $21^{\circ} \mathrm{C}$ and the platelets and leukocytes-containing supernatant was disposed. Erythrocytes were incubated for 48 hours at $37^{\circ} \mathrm{C}$ in vitro at a hematocrit of $0.4 \%$ in Ringer solution containing (in mM) $125 \mathrm{NaCl}, 5 \mathrm{KCl}, 1 \mathrm{MgSO}_{4}, 32 \mathrm{~N}$-2-hydroxyethylpiperazine-N-2-ethanesulfonic acid (HEPES; $\mathrm{pH} 7.4$ ), 5 glucose, and $1 \mathrm{CaCl}_{2}$. Where indicated, erythrocytes were exposed for 48 hours to Elvitegravir (MedChem Express, Princeton, USA). To test for an involvement of p38 kinase, erythrocytes were exposed for 48 hours to a combination of Elvitegravir and p38 kinase inhibitor SB203580 (Tocris bioscience, Bristol, UK). To test for an involvement of caspases, erythrocytes were exposed for 48 hours to a combination of Elvitegravir and pancaspase inhibitor zVAD (Tocris bioscience, Bristol, UK).

\section{Annexin-V-binding and forward scatter}

After incubation under the respective experimental condition, a $150 \mu$ cell suspension was washed in Ringer solution containing $5 \mathrm{mM} \mathrm{CaCl}_{2}$ and then stained with Annexin-V-FITC (1:200 dilution; ImmunoTools, Friesoythe, Germany) in this solution at $37^{\circ} \mathrm{C}$ for $15 \mathrm{~min}$ under protection from light. The annexin-V-abundance at the erythrocyte surface was subsequently determined on a FACS Calibur (BD, Heidelberg, Germany). Annexin-V-binding was measured in FL-1 with an excitation wavelength of $488 \mathrm{~nm}$ and an emission wavelength of $530 \mathrm{~nm}$. A marker (M1) was placed to set an arbitrary threshold between annexin-V-binding cells and control cells. The same threshold was used for untreated and Elvitegravir treated erythrocytes. A dot plot of forward scatter (FSC) vs. side scatter (SSC) was set to linear scale for both parameters. The threshold of forward scatter was set at the default value of " 52 ".

Intracellular $\mathrm{Ca}^{2+}$

After incubation, erythrocytes were washed in Ringer solution and then loaded with Fluo-3/AM (Biotium, Hayward, USA) in Ringer solution containing $5 \mathrm{mM} \mathrm{CaCl}_{2}$ and $5 \mu \mathrm{M}$ Fluo-3/AM. The cells were incubated at $37^{\circ} \mathrm{C}$ for $30 \mathrm{~min}$ and washed once in Ringer solution containing $5 \mathrm{mM} \mathrm{CaCl}_{2}$. The Fluo-3/ AM-loaded erythrocytes were resuspended in $200 \mu$ l Ringer solution. Then, $\mathrm{Ca}^{2+}$-dependent fluorescence intensity was measured in FL-1 with an excitation wavelength of $488 \mathrm{~nm}$ and an emission wavelength of $530 \mathrm{~nm}$ on a FACS Calibur. Afterwards, the geomean of the $\mathrm{Ca}^{2+}$ dependent fluorescence was determined.

Reactive oxidant species (ROS)

Oxidative stress was determined utilizing 2',7'-dichlorodihydrofluorescein diacetate (DCFDA). After incubation, a $150 \mu \mathrm{l}$ suspension of erythrocytes was washed in Ringer solution and then stained with DCFDA (Sigma Aldrich, Hamburg, Germany) in Ringer solution containing DCFDA at a final concentration of $10 \mu \mathrm{M}$. Erythrocytes were incubated at $37^{\circ} \mathrm{C}$ for $30 \mathrm{~min}$ in the dark and then washed two times in Ringer solution. The 


\section{Cellular Physiology Cell Physiol Biochem 2016;38:1111-1120 \\ \begin{tabular}{l|l|l} 
and Biochemistry & DOI: 10.1159/000443061 \\
Published online: March 11, 2016 & $\begin{array}{l}\text { (c) 2016 The Author(s). Published by S. Karger AG, Basel } \\
\text { www.karger.com/cpb }\end{array}$
\end{tabular} \\ Bissinger et al.: Elvitegravir-Induced Eryptosis}

DCFDA-loaded erythrocytes were resuspended in $200 \mu \mathrm{l}$ Ringer solution, and ROS-dependent fluorescence intensity was measured in FL-1 at an excitation wavelength of $488 \mathrm{~nm}$ and an emission wavelength of 530 $\mathrm{nm}$ on a FACS Calibur (BD). Subsequently, the geomean of the ROS-dependent fluorescence was determined

\section{Ceramide abundance}

To determine the ceramide abundance at the erythrocyte surface, a monoclonal antibody was used. After incubation, cells were stained for $1 \mathrm{~h}$ at $37^{\circ} \mathrm{C}$ with $1 \mu \mathrm{g} / \mathrm{ml}$ anti-ceramide antibody (clone MID 15B4; Alexis, Grünberg, Germany) in phosphate-buffered saline (PBS) containing $0.1 \%$ bovine serum albumin (BSA) at a dilution of 1:10. After two washing steps with PBS-BSA, cells were stained for 30 min with polyclonal fluorescein-isothiocyanate (FITC)-conjugated goat anti-mouse IgG and IgM specific antibody (BD Pharmingen, Hamburg, Germany) diluted 1:50 in PBS-BSA. Unbound secondary antibody was removed by repeated washing with PBS-BSA. Samples were then analyzed by flow cytometric analysis in FL-1 at an excitation wavelength of $488 \mathrm{~nm}$ and an emission wavelength of $530 \mathrm{~nm}$. Finally, the geomean of the ceramide dependent fluorescence was determined.

\section{Statistics}

Data are expressed as arithmetic means \pm SEM. As indicated in the figure legends, statistical analysis was made using ANOVA with Tukey's test as post-test and $t$ test as appropriate. $\mathrm{n}$ denotes the number of different erythrocyte specimens studied. Since different erythrocyte specimens used in distinct experiments are differently susceptible to triggers of eryptosis, the same erythrocyte specimens have been used for control and experimental conditions.

\section{Results}

The present study tested whether Elvitegravir stimulates eryptosis, the suicidal erythrocyte death characterized by cell shrinkage and by phospholipid scrambling of the cell membrane with phosphatidylserine translocation to the cell surface.

Erythrocyte volume was estimated from forward scatter, which was determined utilizing flow cytometry. Prior to measurements, the erythrocytes were incubated for 48 hours in Ringer solution without or with Elvitegravir $(0.5-2.5 \mu \mathrm{g} / \mathrm{ml})$. As illustrated in Fig. 1, Elvitegravir decreased erythrocyte forward scatter, an effect reaching statistical significance at $1.5 \mu \mathrm{g} / \mathrm{ml}$ Elvitegravir concentration.

Phosphatidylserine exposing erythrocytes were identified utilizing annexin-V-binding, as determined by flow cytometry. Prior to measurements, the erythrocytes were again
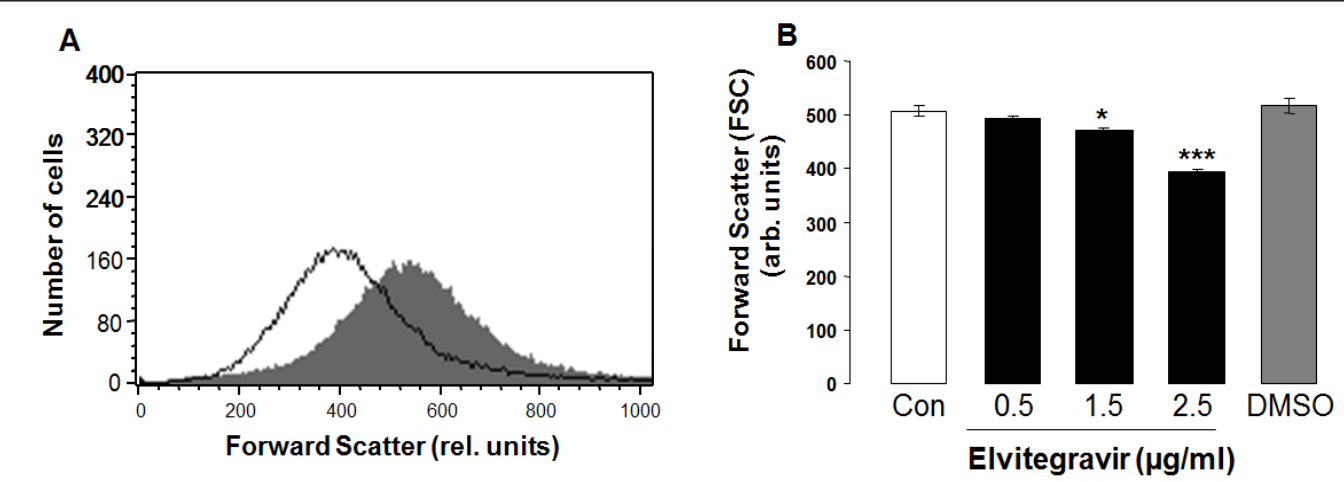

Fig. 1. Effect of Elvitegravir on erythrocyte forward scatter. A. Original histogram of forward scatter of erythrocytes following exposure for 48 hours to Ringer solution without (grey area) and with (black line) presence of $2.5 \mu \mathrm{g} / \mathrm{ml}$ Elvitegravir. B. Arithmetic means \pm SEM $(\mathrm{n}=10)$ of the erythrocyte forward scatter (FSC) following incubation for 48 hours to Ringer solution without (white bar) or with (black bars) Elvitegravir (0.5 - $2.5 \mu \mathrm{g} / \mathrm{ml})$. For comparison, the effect of the solvent DMSO is shown (grey bar). $*(p<0.05)$, $* * *(p<0.001)$ indicate significant difference from the absence of Elvitegravir (ANOVA). 


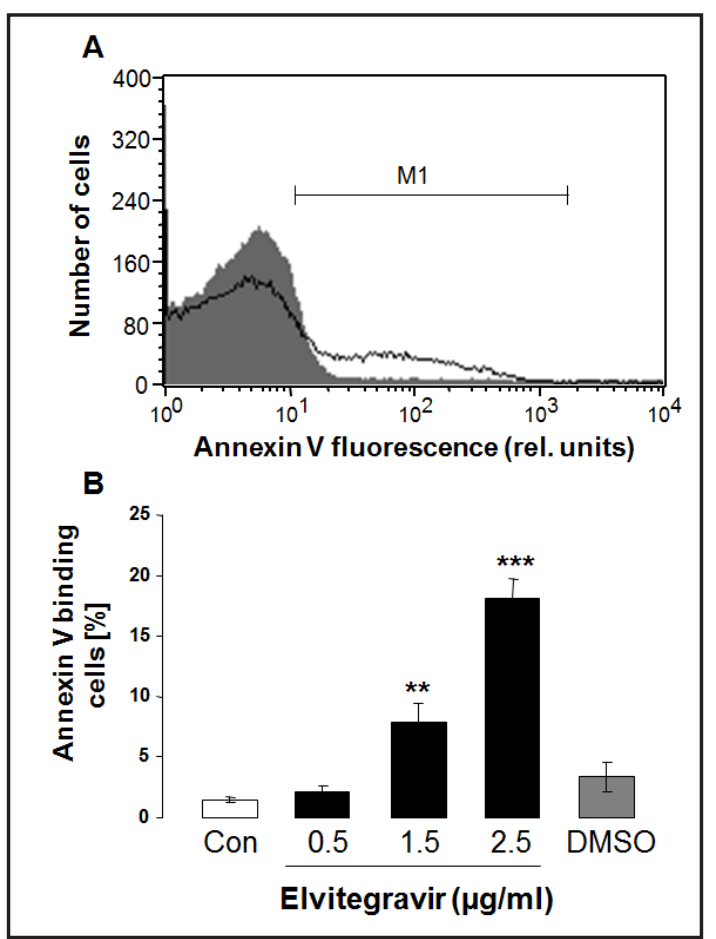

Fig. 2. Effect of Elvitegravir on phosphatidylserine exposure. A. Original histogram of annexin-Vbinding of erythrocytes following exposure for 48 hours to Ringer solution without (grey area) and with (black line) presence of $2.5 \mu \mathrm{g} / \mathrm{ml}$ Elvitegravir. B. Arithmetic means \pm SEM $(n=10)$ of erythrocyte annexin-V-binding following incubation for 48 hours to Ringer solution without (white bar) or with (black bars) Elvitegravir $(0.5-2.5 \mu \mathrm{g} / \mathrm{ml})$. For comparison, the effect of the solvent DMSO is shown (grey bar $) .{ }^{* *}(p<0.01),{ }^{* * *}(p<0.001)$ indicate significant difference from the absence of Elvitegravir (ANOVA).

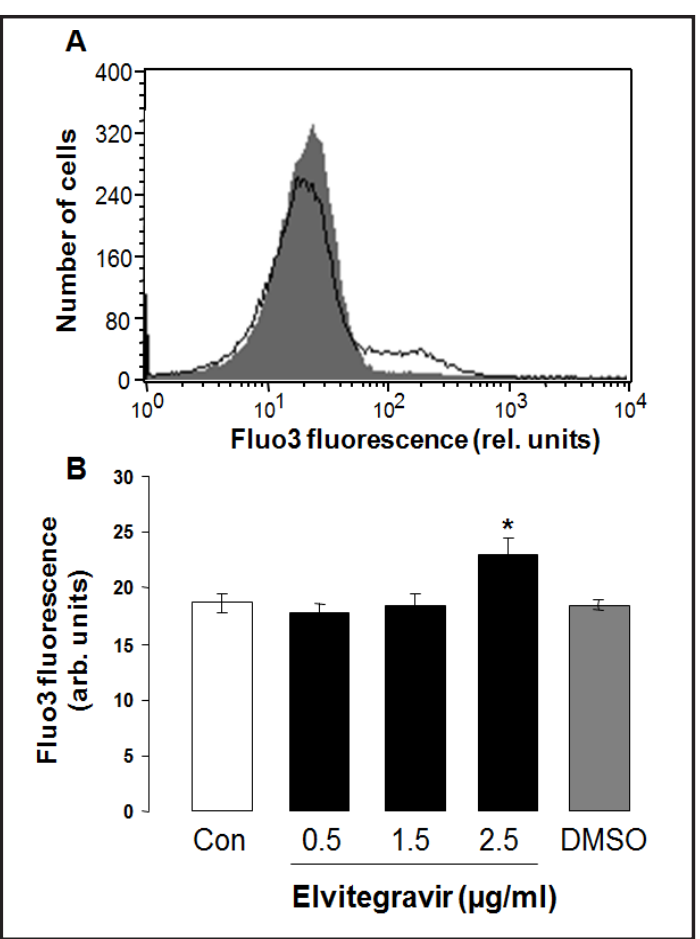

Fig. 3. Effect of Elvitegravir on cytosolic $\mathrm{Ca}^{2+}$ activity. A. Original histogram of Fluo3 fluorescence of erythrocytes following exposure for 48 hours to Ringer solution without (grey area) and with (black line) presence of $2.5 \mu \mathrm{g} / \mathrm{ml}$ Elvitegravir. B. Arithmetic means \pm SEM $(n=10)$ of Fluo3 fluorescence in erythrocytes following incubation for 48 hours to Ringer solution without (white bar) or with (black bars) Elvitegravir (0.5 - $2.5 \mu \mathrm{g} / \mathrm{ml})$. For comparison, the effect of the solvent DMSO is shown (grey bar). $*(p<0.05)$ indicates significant difference from the absence of Elvitegravir (ANOVA).

incubated for 48 hours in Ringer solution without or with Elvitegravir $(0.5-2.5 \mu \mathrm{g} / \mathrm{ml})$. As illustrated in Fig. 2, a 48 hours exposure to Elvitegravir increased the percentage of phosphatidylserine exposing erythrocytes, an effect reaching statistical significance at 1.5 $\mu \mathrm{g} / \mathrm{ml}$ Elvitegravir.

Fluo3 fluorescence was taken as a measure of cytosolic $\mathrm{Ca}^{2+}$ activity $\left(\left[\mathrm{Ca}^{2+}\right]_{\mathrm{i}}\right)$. As illustrated in Fig. 3, a 48 hours exposure to $2.5 \mu \mathrm{g} / \mathrm{ml}$ Elvitegravir significantly increased the Fluo3 fluorescence, an observation pointing to increase of $\left[\mathrm{Ca}^{2+}\right]_{i}$.

A next series of experiments explored whether the Elvitegravir-induced translocation of phosphatidylserine was sensitive to extracellular $\mathrm{Ca}^{2+}$. To this end, erythrocytes were incubated for 48 hours in the absence or presence of $2.5 \mu \mathrm{g} / \mathrm{ml}$ Elvitegravir in the presence or nominal absence of extracellular $\mathrm{Ca}^{2+}$. As shown in Fig. 4, removal of extracellular $\mathrm{Ca}^{2+}$ significantly blunted the effect of Elvitegravir on the percentage of annexin-V-binding erythrocytes. However, even in the absence of extracellular $\mathrm{Ca}^{2+}$, Elvitegravir significantly increased the percentage of annexin-V-binding erythrocytes. Thus, Elvitegravir-induced cell shrinkage was in part, but not fully due to entry of extracellular $\mathrm{Ca}^{2+}$.

Eryptosis is further stimulated by oxidative stress. Reactive oxygen species (ROS) was thus quantified utilizing $2^{\prime}, 7^{\prime}$-dichlorodihydrofluorescein diacetate (DCFDA). As a result, the 


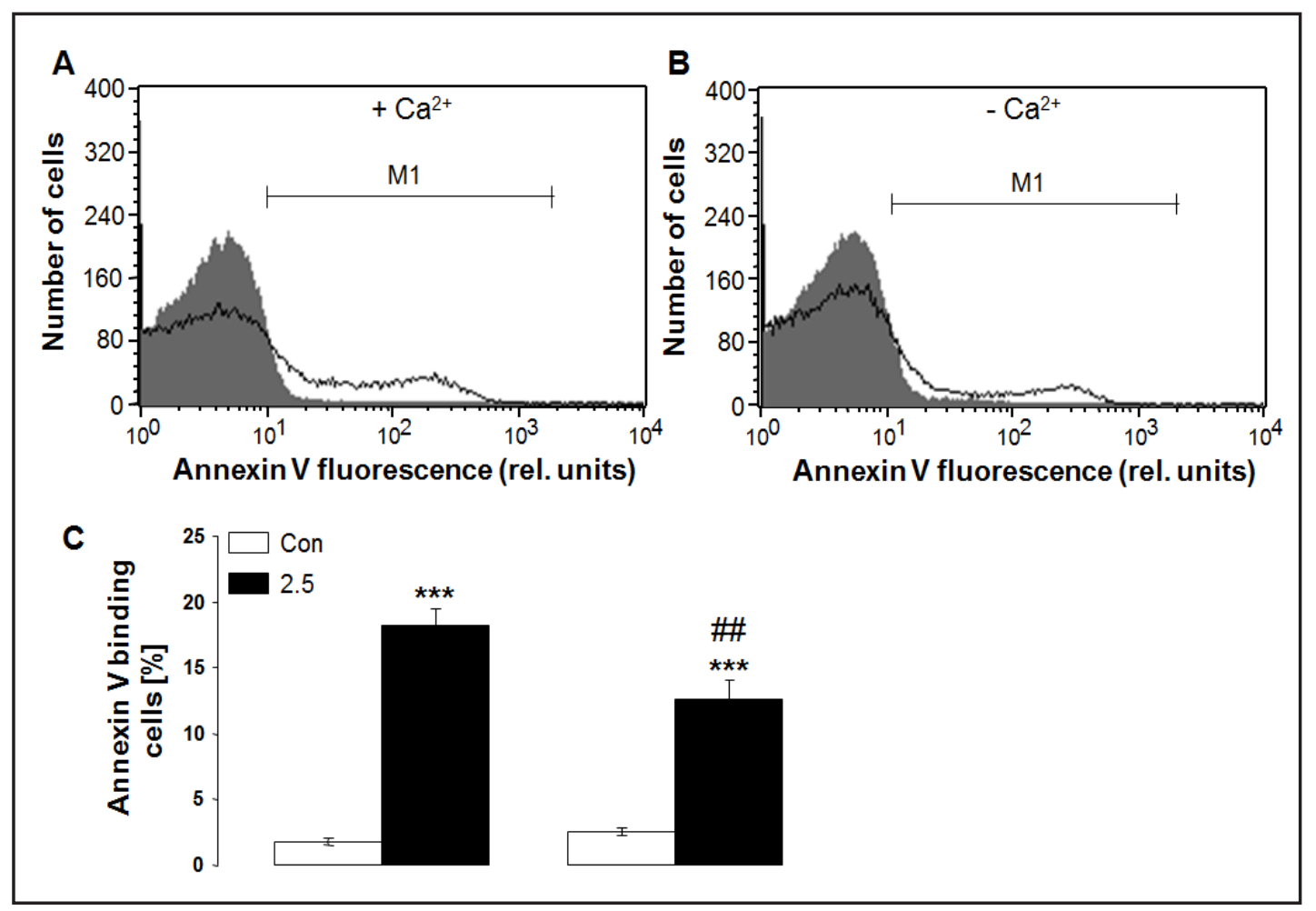

Fig. 4. $\mathrm{Ca}^{2+}$ sensitivity of Elvitegravir-induced phosphatidylserine exposure. A,B. Original histogram of annexin-V-binding of erythrocytes following exposure for 48 hours to Ringer solution without (grey area) and with (black line) Elvitegravir $(2.5 \mu \mathrm{g} / \mathrm{ml})$ in the presence (A) and absence (B) of extracellular $\mathrm{Ca}^{2+}$. C. Arithmetic means \pm SEM $(n=11)$ of annexin-V-binding of erythrocytes after a 48 hours treatment with Ringer solution without (white bars) or with (black bars) Elvitegravir $(2.5 \mu \mathrm{g} / \mathrm{ml})$ in the presence (left bars, $\left.+\mathrm{Ca}^{2+}\right)$ and absence (right bars, $\left.-\mathrm{Ca}^{2+}\right)$ of $\mathrm{Ca}^{2+} .{ }^{* * *}(p<0.001)$ indicates significant difference from the absence of Elvitegravir, \#\# $(p<0.01)$ indicates significant difference from the presence of $\mathrm{Ca}^{2+}$ (ANOVA).

DCFDA fluorescence was similar following exposure to $2.5 \mu \mathrm{g} / \mathrm{ml}$ Elvitegravir (17.7 \pm 0.8 a.u., $\mathrm{n}=11$ ) and in the absence of Elvitegravir (16.9 \pm 0.8 a.u., $\mathrm{n}=11)$. Thus, Elvitegravir did not appreciably induce oxidative stress.

A further stimulator of eryptosis is ceramide. Ceramide abundance at the erythrocyte surface was thus quantified utilizing specific antibodies. As a result, the ceramide abundance was similar following exposure to $2.5 \mu \mathrm{g} / \mathrm{ml}$ Elvitegravir $(16.6 \pm 0.7$ a.u., $\mathrm{n}=11)$ and in the absence of Elvitegravir (16.7 \pm 0.7 a.u., $\mathrm{n}=11$ ). Thus, Elvitegravir did not appreciably induce ceramide abundance.

To explore, whether the effects of Elvitegravir involved p38 kinase activity, the influence of Elvitegravir on annexin-V-binding was tested in the absence or presence of p38 kinase inhibitor SB203580 $(2 \mu \mathrm{M})$. As a result, Elvitegravir $(2.5 \mu \mathrm{g} / \mathrm{ml})$ increased the percentage of phosphatidylserine exposing erythrocytes to similar values in the absence (from $2.1 \pm$ $0.1 \%$ to $20.8 \pm 1.5 \%, \mathrm{n}=5$ ) and in the presence (from $2.4 \pm 0.2 \%$ to $21.6 \pm 1.5 \%, \mathrm{n}=5$ ) of SB203580 $(2 \mu \mathrm{M})$.

A final series of experiments addressed the putative involvement of caspases in Elvitegravir induced eryptosis. To this end, the influence of Elvitegravir on annexin-Vbinding was tested in the absence or presence of pancaspase inhibitor zVAD $(10 \mu \mathrm{M})$. As a result, Elvitegravir $(2.5 \mu \mathrm{g} / \mathrm{ml})$ increased the percentage of phosphatidylserine exposing erythrocytes to similar values in the absence (from $2.4 \pm 0.7 \%$ to $21.8 \pm 2.1 \%, \mathrm{n}=5$ ) and in the presence (from $2.0 \pm 0.5 \%$ to $21.7 \pm 2.5 \%, \mathrm{n}=5$ ) of $\mathrm{zVAD}(10 \mu \mathrm{M})$.

\section{KARGER}




\section{Cellular Physiology Cell Physiol Biochem 2016;38:1111-1120 \\ \begin{tabular}{l|l} 
and Biochemistry Published online: March 11, 2016 & $\begin{array}{l}\text { DO } 2016 \text { The Author(s). Published by S. Karger AG, Basel } \\
\text { www.karger.com/cpb }\end{array}$
\end{tabular} \\ Bissinger et al.: Elvitegravir-Induced Eryptosis}

\section{Discussion}

The present observations reveal a novel effect of Elvitegravir, i.e. the stimulation of eryptosis, the suicidal erythrocyte death. Treatment of erythrocytes from healthy individuals with Elvitegravir results in cell shrinkage and cell membrane scrambling with phosphatidylserine translocation to the erythrocyte surface. The concentrations required for this effect are in the range of peak plasma concentrations determined in Elvitegravir treated patients [56]. A single dose of $150 \mathrm{mg}$ of Elvitegravir has been shown to be followed by an increase of the plasma Elvitegravir concentration to $2.3 \mu \mathrm{g} / \mathrm{ml}$ and a subsequent decline of the plasma Elvitegravir concentration to $0.5 \mu \mathrm{g} / \mathrm{ml}$ [56]. At least in theory, the sensitivity to Elvitegravir induced eryptosis could be enhanced in clinical conditions with accelerated eryptosis, such as dehydration [57], hyperphosphatemia [58], chronic kidney disease (CKD) [59-62], hemolytic-uremic syndrome [63], diabetes [64], hepatic failure [65], malignancy [21], sepsis [66], sickle-cell disease [21], beta-thalassemia [21], Hb-C and G6PD-deficiency [21], as well as Wilsons disease [67].

The effect of Elvitegravir on cell membrane scrambling was blunted by removal of $\mathrm{Ca}^{2+}$ from the extracellular space, indicating that the effect was partially dependent on entry of extracellular $\mathrm{Ca}^{2+}$. The effect of Elvitegravir on cell shrinkage was presumably as well partially due to $\mathrm{Ca}^{2+}$ entry from the extracellular space leading to increase of $\left[\mathrm{Ca}^{2+}\right]_{i}$ with subsequent activation of $\mathrm{Ca}^{2+}$ sensitive $\mathrm{K}^{+}$channels, $\mathrm{K}^{+}$exit, cell membrane hyperpolarization, $\mathrm{Cl}^{-}$exit and thus cellular loss of $\mathrm{KCl}$ with water [20].

However, Elvitegravir triggered cell membrane scrambling even in the absence of extracellular $\mathrm{Ca}^{2+}$, indicating that Elvitegravir triggered cell membrane scrambling in part by mechanisms other than $\mathrm{Ca}^{2+}$ entry. Additional mechanisms triggering eryptosis include oxidative stress, ceramide, activation of p38 kinase or stimulation of caspases [21]. However, Elvitegravir triggered cell membrane scrambling and cell shrinkage without enhancing the ceramide abundance and without inducing oxidative stress. Moreover, the effect of Elvitegravir was insensitive to inhibition of p38 kinase with SB203580 and to inhibition of caspases with zVAD. Thus, the additional mechanism involved in the triggering of eryptosis other than $\mathrm{Ca}^{2+}$ entry remained elusive.

Eryptosis allows the clearance of defective erythrocytes from circulating blood prior to hemolysis [21]. Avoidance of hemolysis is important as hemolysis leads to release of hemoglobin, which passes the renal glomerular filter, precipitates in the acidic lumen of renal tubules, occludes nephrons and thus may lead to renal failure [68]. Eryptosis further counteracts development of parasitemia in malaria, as it is triggered by infection of host erythrocytes and accomplishes elimination of infected erythrocytes.

The clearance of phosphatidylserine exposing erythrocytes from circulating blood may lead to anemia if the loss of erythrocytes outcasts the formation of new erythrocytes by erythropoiesis [21]. Phosphatidylserine exposing erythrocytes further adhere to the vascular wall [69], stimulate blood clotting and thus foster thrombosis [70-72]. Accordingly, stimulation of eryptosis may lead to impairment of microcirculation [22, 70, 73-76].

In conclusion, Elvitegravir triggers eryptosis with cell shrinkage and cell membrane scrambling, an effect in part due to $\mathrm{Ca}^{2+}$ entry.

\section{Acknowledgements}

The authors acknowledge the meticulous preparation of the manuscript by Tanja Loch. The study was supported by the Deutsche Forschungsgemeinschaft and the Open Access Publishing Fund of Tuebingen University.

\section{Disclosure Statement}

The authors of this manuscript state that they have no conflicts of interest to declare. 


\section{Cellular Physiology Cell Physiol Biochem 2016;38:1111-1120 and Biochemistry Published online: March 11, $2016 \quad$\begin{tabular}{l|l} 
DOI: 10.1159/000443061 & $\begin{array}{l}\text { C 2016 The Author(s). Published by S. Karger AG, Basel } \\
\text { www.karger.com/cpb }\end{array}$
\end{tabular} \\ Bissinger et al.: Elvitegravir-Induced Eryptosis}

\section{References}

1 Pandey KK: Critical appraisal of elvitegravir in the treatment of HIV-1/AIDS. HIV AIDS (Auckl) 2014;6:8190.

2 Di Biagio A, Prinapori R, Taramasso L, Gustinetti G, Sticchi L, Bruzzone B, Viscoli C: Which patients have greatest need for elvitegravir/cobicistat/ emtricitabine/tenofovirDF-based therapy? Recent Pat Antiinfect Drug Discov 2014;9:41-51.

3 Lee JS, Calmy A, Andrieux-Meyer I, Ford N: Review of the safety, efficacy, and pharmacokinetics of elvitegravir with an emphasis on resource-limited settings. HIV AIDS (Auckl) 2012;4:5-15.

4 Manzardo C, Gatell JM: Stribild(R) (elvitegravir/cobicistat/emtricitabine/tenofovir disoproxil fumarate): a new paradigm for HIV-1 treatment. AIDS Rev 2014;16:35-42.

5 Temesgen Z: Cobicistat-boosted elvitegravir-based fixed-dose combination antiretroviral therapy for HIV infection. Drugs Today (Barc) 2012;48:765-771.

6 Bonora S, Calcagno A, Trentalange A, Perri GD: Elvitegravir, cobicistat, emtricitabine and tenofovir alafenamide for the treatment of HIV in adults. Expert Opin Pharmacother 2015;10.1517/14656566.2016. 1129401

7 Deeks ED: Elvitegravir: a review of its use in adults with HIV-1 infection. Drugs 2014;74:687-697.

8 Lampiris HW: Elvitegravir: a once-daily, boosted, HIV-1 integrase inhibitor. Expert Rev Anti Infect Ther 2012;10:13-20.

9 Olin JL, Spooner LM, Klibanov OM: Elvitegravir/cobicistat/emtricitabine/tenofovir disoproxil fumarate single tablet for HIV-1 infection treatment. Ann Pharmacother 2012;46:1671-1677.

10 Perry CM: Elvitegravir/cobicistat/emtricitabine/tenofovir disoproxil fumarate single-tablet regimen (Stribild(R)): a review of its use in the management of HIV-1 infection in adults. Drugs 2014;74:75-97.

11 Prinapori R, Di Biagio A: Efficacy, safety, and patient acceptability of elvitegravir/cobicistat/emtricitabine/ tenofovir in the treatment of HIV/AIDS. Patient Prefer Adherence 2015;9:1213-1218.

12 Raffe S, Fisher M: The pharmacokinetics, pharmacodynamics and clinical efficacy of elvitegravir + cobicistat + emtricitabine + tenofovir combination therapy for the treatment of HIV. Expert Opin Drug Metab Toxicol 2015;11:427-435.

13 Ramanathan S, Mathias AA, German P, Kearney BP: Clinical pharmacokinetic and pharmacodynamic profile of the HIV integrase inhibitor elvitegravir. Clin Pharmacokinet 2011;50:229-244.

14 Serrao E, Odde S, Ramkumar K, Neamati N: Raltegravir, elvitegravir, and metoogravir: the birth of "me-too" HIV-1 integrase inhibitors. Retrovirology 2009;6:25.

15 Shimura K, Kodama EN: Elvitegravir: a new HIV integrase inhibitor. Antivir Chem Chemother 2009;20:7985.

16 Wills T, Vega V: Elvitegravir: a once-daily inhibitor of HIV-1 integrase. Expert Opin Investig Drugs 2012;21:395-401.

17 Bissinger R, Waibel S, Lang F: Induction of suicidal erythrocyte death by nelfinavir. Toxins (Basel) 2015;7:1616-1628.

18 Waibel S, Bissinger R, Bouguerra G, Abbes S, Lang F: Saquinavir Induced Suicidal Death of Human Erythrocytes. Cell Physiol Biochem 2015;37:1973-1982.

19 Bissinger R, Waibel S, Bouguerra G, Al Mamun Bhuyan A, Abbes S, Lang F: Enhanced Eryptosis Following Exposure to Lopinavir. Cell Physiol Biochem 2015;37:2486-2495.

20 Lang PA, Kaiser S, Myssina S, Wieder T, Lang F, Huber SM: Role of Ca2+-activated K+ channels in human erythrocyte apoptosis. Am J Physiol Cell Physiol 2003;285:C1553-C1560.

21 Lang E, Lang F: Mechanisms and pathophysiological significance of eryptosis, the suicidal erythrocyte death. Semin Cell Dev Biol 2015;39:35-42.

22 Abed M, Towhid ST, Mia S, Pakladok T, Alesutan I, Borst O, Gawaz M, Gulbins E, Lang F: Sphingomyelinaseinduced adhesion of eryptotic erythrocytes to endothelial cells. Am J Physiol Cell Physiol 2012;303:C991999.

23 Lau IP, Chen H, Wang J, Ong HC, Leung KC, Ho HP, Kong SK: In vitro effect of CTAB- and PEG-coated gold nanorods on the induction of eryptosis/erythroptosis in human erythrocytes. Nanotoxicology 2012;6:847856. 


\section{Cellular Physiology Cell Physiol Biochem 2016;38:1111-1120 \begin{tabular}{l|l} 
and Biochemistry & DOI: 10.1159/000443061 \\
Published online: March 11, 2016 & $\begin{array}{l}\text { (c) 2016 The Author(s). Published by S. Karger AG, Basel } \\
\text { www.karger.com/cpb }\end{array}$
\end{tabular} \\ Bissinger et al.: Elvitegravir-Induced Eryptosis}

24 Maellaro E, Leoncini S, Moretti D, Del Bello B, Tanganelli I, De Felice C, Ciccoli L: Erythrocyte caspase-3 activation and oxidative imbalance in erythrocytes and in plasma of type 2 diabetic patients. Acta Diabetol 2013;50:489-495.

25 Lang E, Bissinger R, Fajol A, Salker MS, Singh Y, Zelenak C, Ghashghaeinia M, Gu S, Jilani K, Lupescu A, Reyskens KM, Ackermann TF, Foller M, Schleicher E, Sheffield WP, Arthur JS, Lang F, Qadri SM: Accelerated apoptotic death and in vivo turnover of erythrocytes in mice lacking functional mitogen- and stressactivated kinase MSK1/2. Sci Rep 2015;5:17316.

26 Alzoubi K, Calabròa S, Bissinger R, Abed M, Faggio C, Lang F: Stimulation of Suicidal Erythrocyte Death by Artesunate. Cell Physiol Biochem 2014;34:2232-2244.

27 Alzoubi K, Egler J, Abed M, Lang F: Enhanced Eryptosis Following Auranofin Exposure. Cell Physiol Biochem 2015;37:1018-1028.

28 Arnold M, Bissinger R, Lang F: Mitoxantrone-induced suicidal erythrocyte death. Cell Physiol Biochem 2014;34:1756-1767.

29 Arnold M, Lang E, Modicano P, Bissinger R, Faggio C, Abed M, Lang F: Effect of nitazoxanide on erythrocytes. Basic Clin Pharmacol Toxicol 2014;114:421-426.

30 Bissinger R, Barking S, Alzoubi K, Liu G, Liu G, Lang F: Stimulation of Suicidal Erythrocyte Death by the Antimalarial Drug Mefloquine. Cell Physiol Biochem 2015;36:1395-1405.

31 Bissinger R, Bouguerra G, Stockinger K, Abbes S, Lang F: Triggering of Suicidal Erythrocyte Death by Topotecan. Cell Physiol Biochem 2015;37:1607-1618.

32 Bissinger R, Fischer S, Jilani K, Lang F: Stimulation of Erythrocyte Death by Phloretin. Cell Physiol Biochem 2014;34:2256-2265.

33 Bissinger R, Lupescu A, Zelenak C, Jilani K, Lang F: Stimulation of eryptosis by cryptotanshinone. Cell Physiol Biochem 2014;34:432-442.

34 Bouguerra G, Aljanadi O, Bissinger R, Abbes S, Lang F: Embelin-Induced Phosphatidylserine Translocation in the Erythrocyte Cell Membrane. Cell Physiol Biochem 2015;37:1629-1640.

35 Bouguerra G, Bissinger R, Abbes S, Lang F: Stimulation of Eryptosis by Narasin. Cell Physiol Biochem 2015;37:1807-1816.

36 Bouguerra G, Bissinger R, Abbes S, Lang F: Zopolrestat Induced Suicidal Death of Human Erythrocytes. Cell Physiol Biochem 2015;37:1537-1546.

37 Briglia M, Fazio A, Faggio C, Laufer S, Alzoubi K, Lang F: Triggering of Suicidal Erythrocyte Death by Ruxolitinib. Cell Physiol Biochem 2015;37:768-778.

38 Briglia M, Fazio A, Signoretto E, Faggio C, Lang F: Edelfosine Induced Suicidal Death of Human Erythrocytes. Cell Physiol Biochem 2015;37:2221-2230.

39 Calabro S, Alzoubi K, Faggio C, Laufer S, Lang F: Triggering of Suicidal Erythrocyte Death Following Boswellic Acid Exposure. Cell Physiol Biochem 2015;37:131-142.

40 Egler J, Lang F: Licochalcone A Induced Suicidal Death of Human Erythrocytes. Cell Physiol Biochem 2015;37:2060-2070.

41 Faggio C, Alzoubi K, Calabro S, Lang F: Stimulation of suicidal erythrocyte death by PRIMA-1. Cell Physiol Biochem 2015;35:529-540.

42 Fazio A, Briglia M, Faggio C, Alzoubi K, Lang F: Stimulation of Suicidal Erythrocyte Death by Garcinol. Cell Physiol Biochem 2015;37:805-815.

43 Jacobi J, Lang E, Bissinger R, Frauenfeld L, Modicano P, Faggio C, Abed M, Lang F: Stimulation of erythrocyte cell membrane scrambling by mitotane. Cell Physiol Biochem 2014;33:1516-1526.

44 Lang E, Jilani K, Bissinger R, Rexhepaj R, Zelenak C, Lupescu A, Lang F, Qadri SM: Vitamin D-Rich Diet in Mice Modulates Erythrocyte Survival. Kidney Blood Press Res 2015;40:403-412.

45 Lang E, Zelenak C, Eberhard M, Bissinger R, Rotte A, Ghashghaeinia M, Lupescu A, Lang F, Qadri SM: Impact of cyclin-dependent kinase CDK4 inhibition on eryptosis. Cell Physiol Biochem 2015;37:1178-1186.

46 Lupescu A, Bissinger R, Goebel T, Salker MS, Alzoubi K, Liu G, Chirigiu L, Mack AF, Qadri SM, Lang F: Enhanced suicidal erythrocyte death contributing to anemia in the elderly. Cell Physiol Biochem 2015;36:773-783.

47 Lupescu A, Bissinger R, Herrmann T, Oswald G, Jilani K, Lang F: Induction of suicidal erythrocyte death by novobiocin. Cell Physiol Biochem 2014;33:670-680.

48 Lupescu A, Bissinger R, Warsi J, Jilani K, Lang F: Stimulation of erythrocyte cell membrane scrambling by gedunin. Cell Physiol Biochem 2014;33:1838-1848. 


\section{Cellular Physiology Cell Physiol Biochem 2016;38:1111-1120 \begin{tabular}{l|l} 
and Biochemistry & DOI: 10.1159/000443061 \\
Published online: March 11, 2016 & $\begin{array}{l}\text { (c) 2016 The Author(s). Published by S. Karger AG, Basel } \\
\text { www.karger.com/cpb }\end{array}$
\end{tabular} \\ Bissinger et al.: Elvitegravir-Induced Eryptosis}

49 Malik A, Bissinger R, Calabro S, Faggio C, Jilani K, Lang F: Aristolochic Acid Induced Suicidal Erythrocyte Death. Kidney Blood Press Res 2014;39:408-419.

50 Officioso A, Alzoubi K, Manna C, Lang F: Clofazimine Induced Suicidal Death of Human Erythrocytes. Cell Physiol Biochem 2015;37:331-341.

51 Oswald G, Alzoubi K, Abed M, Lang F: Stimulation of suicidal erythrocyte death by ribavirin. Basic Clin Pharmacol Toxicol 2014;114:311-317.

52 Peter T, Bissinger R, Enkel S, Alzoubi K, Oswald G, Lang F: Programmed erythrocyte death following in vitro Treosulfan treatment. Cell Physiol Biochem 2015;35:1372-1380.

53 Stockinger K, Bissinger R, Bouguerra G, Abbes S, Lang F: Enhanced Eryptosis Following Exposure to Carnosic Acid. Cell Physiol Biochem 2015;37:1779-1791.

54 Tesoriere L, Attanzio A, Allegra M, Cilla A, Gentile C, Livrea MA: Oxysterol mixture in hypercholesterolemiarelevant proportion causes oxidative stress-dependent eryptosis. Cell Physiol Biochem 2014;34:10751089.

55 Zierle J, Bissinger R, Egler J, Lang F: Lapatinib Induced Suicidal Death of Human Erythrocytes. Cell Physiol Biochem 2015;37:2275-2287.

56 Shiomi M, Matsuki S, Ikeda A, Ishikawa T, Nishino N, Kimura M, Irie S: Effects of a protein-rich drink or a standard meal on the pharmacokinetics of elvitegravir, cobicistat, emtricitabine and tenofovir in healthy Japanese male subjects: a randomized, three-way crossover study. J Clin Pharmacol 2014;54:640-648.

57 Abed M, Feger M, Alzoubi K, Pakladok T, Frauenfeld L, Geiger C, Towhid ST, Lang F: Sensitization of erythrocytes to suicidal erythrocyte death following water deprivation. Kidney Blood Press Res 2013;37:567-578.

58 Voelkl J, Alzoubi K, Mamar AK, Ahmed MS, Abed M, Lang F: Stimulation of suicidal erythrocyte death by increased extracellular phosphate concentrations. Kidney Blood Press Res 2013;38:42-51.

59 Abed M, Artunc F, Alzoubi K, Honisch S, Baumann D, Foller M, Lang F: Suicidal erythrocyte death in endstage renal disease. J Mol Med (Berl) 2014;92:871-879.

60 Ahmed MS, Langer H, Abed M, Voelkl J, Lang F: The uremic toxin acrolein promotes suicidal erythrocyte death. Kidney Blood Press Res 2013;37:158-167.

61 Polak-Jonkisz D, Purzyc L: Ca(2+) influx versus efflux during eryptosis in uremic erythrocytes. Blood Purif 2012;34:209-210; author reply 210.

62 Calderon-Salinas JV, Munoz-Reyes EG, Guerrero-Romero JF, Rodriguez-Moran M, Bracho-Riquelme RL, Carrera-Gracia MA, Quintanar-Escorza MA: Eryptosis and oxidative damage in type 2 diabetic mellitus patients with chronic kidney disease. Mol Cell Biochem 2011;357:171-179.

63 Lang PA, Beringer O, Nicolay JP, Amon O, Kempe DS, Hermle T, Attanasio P, Akel A, Schafer R, Friedrich B, Risler T, Baur M, Olbricht CJ, Zimmerhackl LB, Zipfel PF, Wieder T, Lang F: Suicidal death of erythrocytes in recurrent hemolytic uremic syndrome. J Mol Med (Berl) 2006;84:378-388.

64 Nicolay JP, Schneider J, Niemoeller OM, Artunc F, Portero-Otin M, Haik G Jr, Thornalley PJ, Schleicher E, Wieder T, Lang F: Stimulation of suicidal erythrocyte death by methylglyoxal. Cell Physiol Biochem 2006;18:223-232.

65 Lang E, Gatidis S, Freise NF, Bock H, Kubitz R, Lauermann C, Orth HM, Klindt C, Schuier M, Keitel V, Reich M, Liu G, Schmidt S, Xu HC, Qadri SM, Herebian D, Pandyra AA, Mayatepek E, Gulbins E, Lang F, Haussinger D, Lang KS, Foller M, Lang PA: Conjugated bilirubin triggers anemia by inducing erythrocyte death. Hepatology 2015;61:275-284.

66 Kempe DS, Akel A, Lang PA, Hermle T, Biswas R, Muresanu J, Friedrich B, Dreischer P, Wolz C, Schumacher U, Peschel A, Gotz F, Doring G, Wieder T, Gulbins E, Lang F: Suicidal erythrocyte death in sepsis. J Mol Med (Berl) 2007;85:273-281.

67 Lang PA, Schenck M, Nicolay JP, Becker JU, Kempe DS, Lupescu A, Koka S, Eisele K, Klarl BA, Rubben H, Schmid KW, Mann K, Hildenbrand S, Hefter H, Huber SM, Wieder T, Erhardt A, Haussinger D, Gulbins E, Lang F: Liver cell death and anemia in Wilson disease involve acid sphingomyelinase and ceramide. Nat Med 2007;13:164-170.

68 Harrison HE, Bunting H, Ordway NK, Albrink WS: The Pathogenesis of the Renal Injury Produced in the Dog by Hemoglobin or Methemoglobin. J Exp Med 1947;86:339-356.

69 Borst O, Abed M, Alesutan I, Towhid ST, Qadri SM, Foller M, Gawaz M, Lang F: Dynamic adhesion of eryptotic erythrocytes to endothelial cells via CXCL16/SR-PSOX. Am J Physiol Cell Physiol 2012;302:C644-C651. 


\section{Cellular Physiology Cell Physiol Biochem 2016;38:1111-1120 \begin{tabular}{l|l} 
DOI: 10.1159/000443061 & O 2016 The Author(s). Published by S. Karger AG, Basel \\
and Biochemisarger.com/cpb
\end{tabular} \\ Bissinger et al.: Elvitegravir-Induced Eryptosis}

70 Andrews DA, Low PS: Role of red blood cells in thrombosis. Curr Opin Hematol 1999;6:76-82.

71 Chung SM, Bae ON, Lim KM, Noh JY, Lee MY, Jung YS, Chung JH: Lysophosphatidic acid induces thrombogenic activity through phosphatidylserine exposure and procoagulant microvesicle generation in human erythrocytes. Arterioscler Thromb Vasc Biol 2007;27:414-421.

72 Zwaal RF, Comfurius P, Bevers EM: Surface exposure of phosphatidylserine in pathological cells. Cell Mol Life Sci 2005;62:971-988.

73 Closse C, Dachary-Prigent J, Boisseau MR: Phosphatidylserine-related adhesion of human erythrocytes to vascular endothelium. Br J Haematol 1999;107:300-302.

74 Gallagher PG, Chang SH, Rettig MP, Neely JE, Hillery CA, Smith BD, Low PS: Altered erythrocyte endothelial adherence and membrane phospholipid asymmetry in hereditary hydrocytosis. Blood 2003;101:46254627.

75 Pandolfi A, Di Pietro N, Sirolli V, Giardinelli A, Di Silvestre S, Amoroso L, Di Tomo P, Capani F, Consoli A, Bonomini M: Mechanisms of uremic erythrocyte-induced adhesion of human monocytes to cultured endothelial cells. J Cell Physiol 2007;213:699-709.

76 Wood BL, Gibson DF, Tait JF: Increased erythrocyte phosphatidylserine exposure in sickle cell disease: flowcytometric measurement and clinical associations. Blood 1996;88:1873-1880. 